\title{
DEVELOPING A SUSTAINABLE PERFORMANCE MEASUREMENT FRAMEWORK FOR THE HOSPITALITY INDUSTRY: AN EMPIRICAL STUDY WITH IMPLICATIONS FOR THE COVID-19 PANDEMIC
}

Tahniyath Fatima \& Saïd Elbanna

\section{(1) INTRODUCTION}

- Sustainable Tourism is an emerging research topic which the hospitality industry is increasingly adopting and implementing (Kim et al., 2019). Despite this topic's importance, there is a lack in usage of multi-dimensional performance measurement systems assessing sustainable tourism (Elbanna et al., 2015; Sainaghi et al., 2019)

COVID-19 pandemic that began in December 2019 in Wuhan, China (WHO, 2020) has impacted the hospitality industry, more than any other service industry, where the industry is facing difficulty in maintaining its business (Moniz, 2020; Petersen et al., 2020), and can decrease the industry's GDP contribution by as much as 50\% to 70\% (Chakraborty \& Maity, 2020).

- Indian travel and tourism industry ranks quite low globally in the bottom $20 \%$ when it comes to two sustainable development goals (SDGs) of (1) ensuring a healthy and hygienic environment and (2) enhancing environment sustainability (WEF, 2019).

\section{(2) RESEARCH CONTRIBUTIONS}

- Enhancing current literature on sustainability and performance measurement through developing a new sustainable performance measurement framework from the balanced scorecard (BSC) perspective for the hospitality industry, which is the first of its kind in this industry

- Assisting the hospitality industry, in particular, and other industries, in general, in light of the COVID-19 pandemic, by developing a new perspective for health and safety which is also the first of its kind in the hospitality literature.

- Enabling the Indian travel and tourism sector to efficiently satisfy its sustainable development goals (SDGs) and thereby, contribute to improving the country's overall SDG index.

\section{(3) METHODS \& ANALYSIS}

\section{Methodology:} A three-stage mixed methods research design was employed to develop the framework as shown in the figure on the right Data analysis: Partial-least square structural equation modeling (PLS-SEM) approach is used.

\section{(4) SUSTAINABLE PERFORMANCE MEASUREMENT FRAMEWORK}

- The proposed framework consists of seven perspectives, of which six are non-financial and one is financial in nature. The non-financial perspectives consist of learning and growth, internal business, customer, health and safety, environmental, and social.

- A new 'health and safety' perspective was proposed that enables hotels to ensure a healthy and hygienic environment during the COVID-19 pandemic amongst employees and customers.

- Some of the crucial after-effects of COVID-19 on the hospitality industry as identified by the managers have been quoted on the right.

\section{(4) SUSTAINABLE PERFORMANCE MEASUREMENT FRAMEWORK (contd.)}

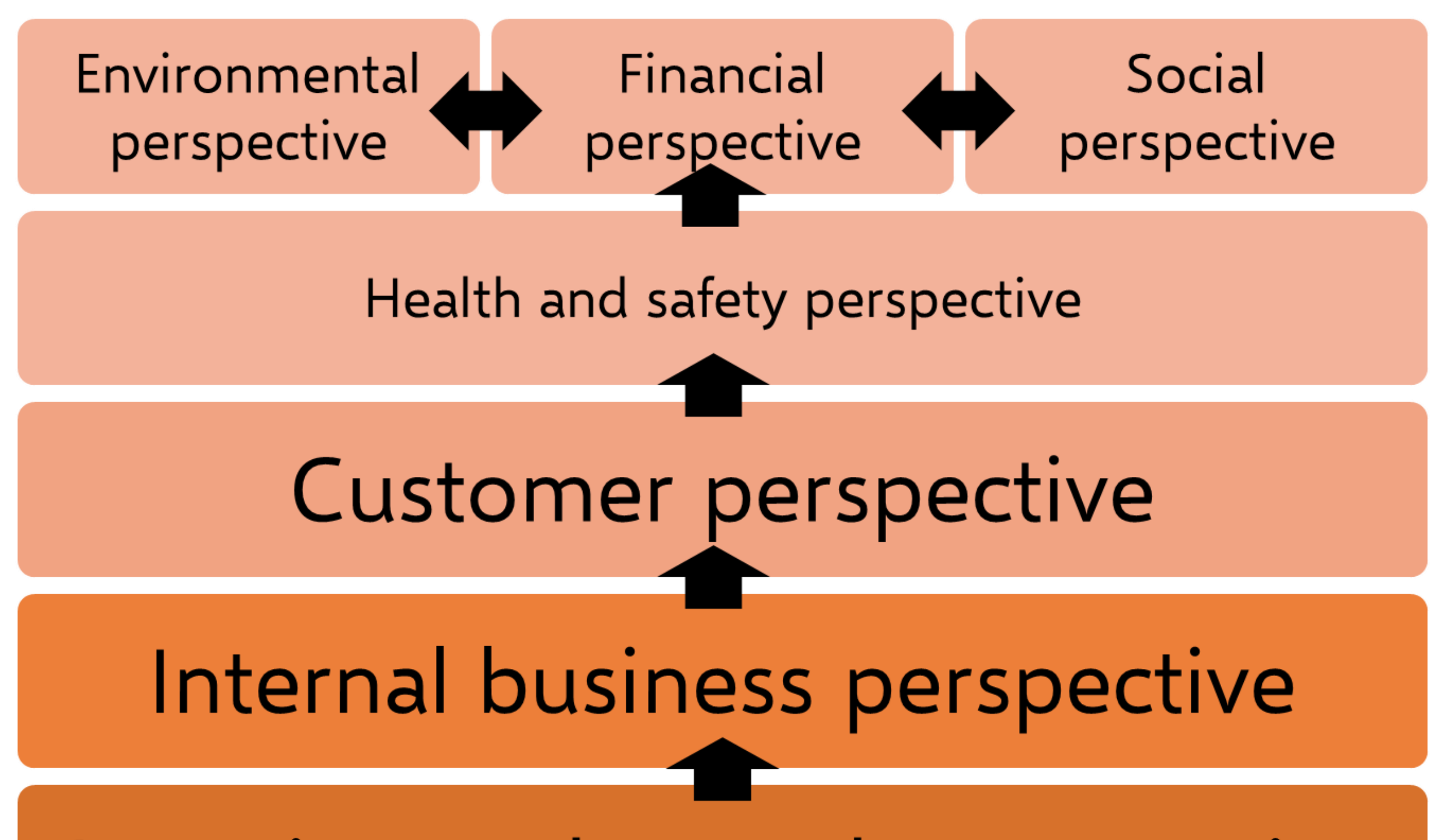

\section{Learning and growth perspective}

Financial
perspective
Social perspective
Environmental
perspective
Health and safety
perspective
Customer
perspective
Internal business
perspective
Learning and
growth perspective

\begin{tabular}{|c|c|}
\hline $\begin{array}{l}\text { Gross operating profit } \\
\text { Return on sale } \\
\text { Revenue per available room }\end{array}$ & $\begin{array}{l}\text { - Donations to local society } \\
\text { - Environment spending (e.g. investing in sewage treatment plants) } \\
\text { - Health and safety spending (e.g. food safety, fire safety, hygiene development) }\end{array}$ \\
\hline $\begin{array}{l}\text { - Complying with social regulations } \\
\text { - } i \text { imititg negative social impact beyond compliance } \\
\text { Creation of new job opportunities }\end{array}$ & $\begin{array}{l}\text { - Implementation of safety measures for female staff } \\
- \text { Contributing towards providing education to the underprivileged }\end{array}$ \\
\hline $\begin{array}{l}\text { Reduced pollution and service costs } \\
\text { Reduced evvironmental fines } \\
\text { Increased image in environmental protection }\end{array}$ & $\begin{array}{l}\text { - Increases in products with environmentally friendly design } \\
\text { - Awareness and understanding of current trends in environmental regulations }\end{array}$ \\
\hline $\begin{array}{l}\text { Safe hospitality service provisionst to customers } \\
\text { Customer feedback on safe and hygienic hospitality } \\
\text { Implementing mandatory regular health checkups for }\end{array}$ & - Training employees on health and safety guidelines \\
\hline $\begin{array}{l}\text { Verbal/anecdotal customer feedback via staff } \\
\text { Market share } \\
\text { Market share growth }\end{array}$ & $\begin{array}{l}\text { Domestic market share growth } \\
\text { Meeting customerdemand for green services } \\
\text { Customer feeddack on availability of ecoffirendly amenities (e.g. reusing sheets } \\
\text { and linens, conserving venergy and water use etc.) }\end{array}$ \\
\hline $\begin{array}{l}\text { Productivity levels, e.g., labor productivity } \\
\text { Effficiency of operations, e.g., booking, room service } \\
\text { Programmes to monitor and reduce use of resources }\end{array}$ & - Flexibility in serving customer ne \\
\hline $\begin{array}{l}\text { Number of new 'green' services (i.e, provision of } \\
\text { eco-friendly amenitits, reduce, reuse and recycle } \\
\text { options for hotel amenities, energy saving } \\
\text { intitititese stc). }\end{array}$ & $\begin{array}{l}\text { Building network of relationships with stakeholders } \\
\text { Staff capabilities } \\
\text { Training emplosees on eco-friendly behavior } \\
\text { Employee feedback on skills development }\end{array}$ \\
\hline
\end{tabular}
Gross operating profit Colying with social regulations
The seven perspectives inherent to the proposed framework for the hospitality industry are theorized to have causal relationships amongst themselves in the manner depicted in the figure on the left.

Managers can effectively assess their organizational performance through utilizing the proposed framework with the corresponding indicators which are devised specific to the hospitality industry.

- The green indicators represent the sustainability-oriented measures.

\section{(5) CONCLUSIONS}

- The proposed framework can be effectively utilized to assess hotel performance. Further, given its strategic nature, hotel managers can refine the indicators to make them more suitable to the strategy in place or focus on specific indicators and/or perspectives to ensure an accurate measurement of their hotel's strategic objectives.

- The newly proposed health and safety perspective considers the impact of COVID-19 pandemic on the hospitality industry and enables the hotels to evaluate their performance towards exploring a road to recovery by stressing on the health and well-being of both employees and tourists, in order to achieve a safe and hygienic environment.

- The results indicated that the hospitality industry in India is actively assessing the input and process indicators of performance measurement as opposed to output indicators.

- The proposed framework has been tailored to the hospitality industry in India and also can be extended to hotels in South Asian countries (e.g., Bangladesh, Nepal, Pakistan and Sri Lanka), and also is expected to act as a stepping stone for many studies that are encouraged to advance this line of research in other parts of the world as well. 